\title{
Diagnostic and Prognostic Potential of Biomarkers CYFRA 21.1, ERCC1, p53, FGFR3 and TATI in Bladder Cancers
}

\author{
Milena Matuszczak and Maciej Salagierski * (10) \\ Department of Urology, Collegium Medicum, University of Zielona Góra, 65-046 Zielona Góra, Poland; \\ matuszczakmilena@gmail.com \\ * Correspondence: m.salagierski@cm.uz.zgora.pl
}

Received: 16 April 2020; Accepted: 5 May 2020; Published: 9 May 2020

\begin{abstract}
The high occurrence of bladder cancer and its tendency to recur in combination with a lifelong surveillance make the treatment of superficial bladder cancer one of the most expensive and time-consuming. Moreover, carcinoma in situ often leads to muscle invasion with an unfavorable prognosis. Currently, invasive methods including cystoscopy and cytology remain a gold standard. The aim of this study was to explore urine-based biomarkers to find the one with the best specificity and sensitivity, which would allow optimizing the treatment plan. In this review, we sum up the current knowledge about Cytokeratin fragments (CYFRA 21.1), Excision Repair Cross-Complementation 1 (ERCC1), Tumour Protein p53 (Tp53), Fibroblast Growth Factor Receptor 3 (FGFR3), Tumor-Associated Trypsin Inhibitor (TATI) and their potential applications in clinical practice.
\end{abstract}

Keywords: biomarkers; bladder cancer; tumor markers; prognosis

\section{Introduction: Bladder Cancer Issues and Biomarkers}

Bladder cancer is the most common urinary site of malignancy and the second most common reason of cancer deaths from the genitourinary tract after prostate cancer in the United States, with 81,400 new cases and 17,980 deaths in the year 2020 [1]. Globally there are about 430,000 new cases diagnosed each year [2].

Favorably, non-invasive lesions constitute approximately $75-80 \%$ of newly diagnosed urothelial bladder cancers (UBC). More than $50 \%$ of UBCs are caused by smoking. Other important factors include occupational exposure to aromatic amines and polycyclic hydrocarbons. Less evident is the impact of diet and environmental pollution. Increasing data indicate that genetic predisposition plays a role in UBC pathogenesis [2-4].

There are two major groups of patients with distinct prognosis and molecular features.

Carcinoma in situ (CIS) and tumors staged as Ta, T1 are grouped as non-muscle-invasive bladder cancers (NMIBC) [5]. NMIBC patients generally have a significant risk of recurrence and potential clinical course for progression [6] but their life expectancy is long and the cancer rarely progresses to muscle invasion. For NMIBC, the major problem is that after the initial transurethral resection of the bladder (TURB), they characteristically recur in $50-70 \%$ of cases, with only approximately $10-20 \%$ of cases progressing to muscle-invasive bladder cancer (MIBC) [7].

Muscle-invasive tumors very often metastasize and are usually diagnosed de novo, the prognosis is unfavorable and for decades there has been made no major innovation in therapy. Papillary non-invasive cancers (pTa) grow up from carcinoma in situ (CIS) of the urothelium (frequently TP53-mutated, a high-grade lesion) and often metastasize and evolve into muscle invasion [8]. Robertson et al. demonstrated that MIBC shows high overall mutation rates but fortunately most of 
them seem to be passenger variation without any functional meaning, or repeated genetic alterations including the TP53, FGFR3, PIK3CA and RB1 genes' mutations [4,9].

Muscle-invasive bladder cancer (MIBC) is a high risk but potentially curable disease. Unfortunately, still nearly half of patients die from MIBC despite getting the appropriate treatment $[10,11]$. The major problem in the management of superficial bladder cancer is its tendency to recur. Lifelong surveillance with a relatively long-life expectancy (5-year survival rate $>90 \%$ ) makes it the most expensive and time-consuming malignancy to treat.

In recent years, a great effort has been put in the search for new potential biomarkers such as protein 53 (p53), ERCC1, CYFRA 21.1, FGFR3 and TATI in the prognosis and prediction of bladder cancer. The FGFR3 mutations could be a marker of low-grade and early stage tumors, while the changes in p53 appear better in detecting high-grade or advanced cancers.

\section{Diagnostic and Prognostic Potential of Bladder Cancer Biomarkers}

\subsection{Cytokeratin Fragment 21.1 (CYFRA 21.1)}

Cytokeratin fragments (CYFRA 21.1) is an ELISA-based assay that detects the concentration of a soluble fragment of cytokeratin 19 by using two monoclonal antibodies [12]. The studies have shown that the differentiation between liquid biopsies of healthy (non-cancer) individuals and BC patients may be done using this biomarker.

Authors [13] concluded that both serum and urine CYFRA 21.1 present decisive indexes for bladder cancer diagnosis. They made a systematic analysis which indicated the pooled sensitivities and specificities for the serum and urine CYFRA 21.1 were of $42 \%, 82 \%, 94 \%$ and $80 \%$, respectively. The areas under the receiver operating characteristic curves (AUC) for the serum and urine CYFRA 21.1 were in sequence 0.88 and 0.87 (Table 1 ).

In an extensive meta-analysis of three case-control studies Kuang [14] confirmed that urinary or serum samples containing CYFRA21.1 can be used as diagnostic biomarkers and for the distinction between local and metastatic bladder cancer. In this meta-analysis, all healthy individuals had a lower CYFRA21.1 level than patients with bladder cancer. The locally invasive disease showed also lower CYFRA 21.1 levels than the subgroup with metastatic bladder cancer. Notwithstanding, between patients with bladder cancer stage I and stage II, and among the group of patients with local stage II and III were no significant differences in the CYFRA21.1 level. Therefore, CYFRA 21.1 cannot be useful in differentiating grades I-III of local bladder cancer but may be used as a diagnostic biomarker and to detect metastases.

Nisman [15] evaluated that for detecting transitional cell tumors that were grade 1 with CYFRA 21.1 measured in urine samples gave a three-times higher sensitivity compared with the sensitivity of cytology.

CYFRA 21.1 has a high sensitivity for identifying high-grade and CIS tumors and a greater accuracy for the detection of primary tumors than for the recurrence, but it cannot be used for an early detection of BC. The specificity of this test is between $73 \%$ and $86 \%$ and the sensitivity is between $70 \%$ and $90 \%[12,15,16]$.

Andreadis and colleagues [17] analyzed a group of 142 patients with invasive bladder cell carcinoma, including 56 patients with stage T1-4 N0 M0 and 86 with involved lymph nodes or distant metastases. The control group contained 33 healthy volunteers. Seven per cent of patients with the locally advanced disease and $66 \%$ of patients with the metastatic disease had an elevated level of this biomarker. CYFRA 21.1 may also be a useful tool in indicating the response to chemotherapy.

Importantly, Nisman and colleagues [15] showed that CYFRA 21.1 detected $100 \%$ of CIS, $92.8 \%$ of invasive bladder tumors (T2 or higher classification) and $91.9 \%$ of grade 3 tumors. The CYFRA 21.1 assay identified almost all tumors (with the exception of only one) that had a positive cytology. Moreover, the assay detected $65 \%$ of recurrent tumors and $71 \%$ of primary tumors that were omitted by cytopathology. 
Unfortunately, CYFRA 21.1 is a false positive in the group of patients with urinary tract infections, stones, history of pelvic radiotherapy, urethral catheterization or BCG intravesical instillation within the three previous months. Even years following intravesical immunotherapy with the BCG level of urinary CYFRA 21.1 may be elevated.

Importantly, the abnormal serum level of CYFRA 21.1 [18] corresponds with a worse response.

In conclusion, Washino [19] observed that serum CYFRA 21.1 might be a marker of high-grade and advanced urothelial carcinoma. On the contrary, CEA and CA19-9 were not demonstrated as potential tumor markers.

The centrifugation step in the methodology is the very important one to improve the precision of this assay by removing cells' debris that contains a large amount of CYFRA 21.1, i.e., after this process, a significant decrease in the number of true positive and false positive results can be observed [20].

CYFRA 21.1 is considered as one of the best urinary markers for bladder cancer. Jeong and colleagues noticed that CYFRA 21.1 and NMP22 are the most effective at predicting bladder cancer [21]. However, there is a disadvantage being that the concentrations of both markers are strongly influenced by benign urological diseases, intravesical instillations and also a disappointing performance in low-stage bladder cancer. 
Table 1. Predictive capacity of bladder cancer biomarkers.

\begin{tabular}{|c|c|c|c|c|c|c|c|c|c|}
\hline $\begin{array}{l}\text { Protein } \\
\text { Name }\end{array}$ & $\begin{array}{l}\text { Gene } \\
\text { Symbol }\end{array}$ & Purpose & $\begin{array}{l}\text { Diagnostic } \\
\text { Value }\end{array}$ & Prognostic Value & $\begin{array}{l}\text { FDA } \\
\text { Approve }\end{array}$ & Method & $\begin{array}{l}\text { Samples } \\
\text { Used (No. } \\
\text { Patients) }\end{array}$ & $\begin{array}{l}\text { Predicitive } \\
\text { Capacity }\end{array}$ & Reference \\
\hline \multirow[t]{2}{*}{ CYFRA 21.1} & \multirow[t]{2}{*}{ KRT19 } & \multirow[t]{2}{*}{$\begin{array}{l}\text { Diagnostic } \\
\text { and } \\
\text { surveillance }\end{array}$} & \multirow[t]{2}{*}{$\begin{array}{l}\text { Both serum and } \\
\text { urine CYFRA } \\
21.1 \text { levels } \\
\text { provide an } \\
\text { effective index } \\
\text { for the } \\
\text { diagnosis of BC. }\end{array}$} & \multirow{2}{*}{$\begin{array}{l}\text { High risk of malignancy- significantly } \\
\text { higher serum level of CYFRA 21.1 } \\
\text { according to tumour stage }(p<0.01) \\
\text { and grade }(p<0.05) \text {. Patients with } \\
\text { increased CYFRA 21.1 level had } \\
\text { significantly worse disease-specific } \\
\text { survival }(p<0.0001, \text { log rank test) [19]. } \\
\text { Moreover, patients with metastases } \\
\text { had a higher CYFRA } 21.1 \text { level than } \\
\text { those with locally invasive BC [14]. }\end{array}$} & \multirow[t]{2}{*}{ No } & \multirow{2}{*}{$\begin{array}{l}\text { Meta-analysis performed using STATA } 12.0 \text { on the base of } \\
\text { studies had published before } 2 \text { November } 2014 \text { in EMBASE, } \\
\text { Web of Science and Medline databases. Quality of the studies } \\
\text { was assessed by revised QUADAS tools, all of selected studies } \\
\text { were English language publications and evaluate diagnostic } \\
\text { accuracy of CYFRA } 21.1 \text { in patients with BC. Systematic review } \\
\text { included } 13 \text { studies and } 1,262 \text { BC and } 1,233 \text { non-bladder cancer } \\
\text { patients. } 8 \text { studies measured urine and } 5 \text { serum level of CYFRA } \\
\text { 21.1. In serum detection of CYFRA } 21.1471 \text { BC and } 296 \text { non- } \\
\text { bladder cancer patients were analyzed. Urine CYFRA } 21.1 \\
\text { studies included } 538 \text { BC and } 678 \text { non-bladder cancer patients. }\end{array}$} & $\begin{array}{c}\text { Urine }(n= \\
538 \mathrm{BC} / 678 \\
\text { control) }\end{array}$ & $\begin{array}{l}\text { Sensitivity } \\
\quad=82 \% \\
\text { Specificity } \\
=80 \% \\
\text { AUC }= \\
0.87\end{array}$ & \multirow[t]{2}{*}{$\begin{array}{c}\text { [12-14, } \\
19]\end{array}$} \\
\hline & & & & & & & $\begin{array}{l}\text { Serum }(n \\
\quad=471 \\
\text { BC/296 } \\
\text { control })\end{array}$ & $\begin{array}{l}\text { Sensitivity } \\
\quad=42 \% \\
\text { Specificity } \\
=94 \% \\
\text { AUC }= \\
0.88\end{array}$ & \\
\hline $\begin{array}{l}\text { DNA } \\
\text { EXCISION } \\
\text { REPAIR } \\
\text { PROTEIN } \\
\text { ERCC-1 }\end{array}$ & ERCC1 & $\begin{array}{l}\text { Diagnostic } \\
\text { and } \\
\text { surveillance }\end{array}$ & $\begin{array}{c}71.3 \%(308 / 432) \\
\text { of cases was } \\
\text { ERCC1 positive. } \\
\text { Ta }=3.2 \% \text { T1 }= \\
11.7 \% \mathrm{~T} 2= \\
21.4 \% \mathrm{~T} 3= \\
45.1 \% \mathrm{~T} 4= \\
18.5 \% \\
\text { CIS }=8.1 \% \\
\text { LG }=20.8 \% \\
\text { HG }=79.2 \%\end{array}$ & $\begin{array}{l}\text { ERCC positive tumour had } \\
\text { significantly better disease-free } \\
\text { survival (HR } 0.7, p=0.028 \text { ) than } \\
\text { ERCC1 negative tumours. ERCC1 } \\
\text { positive tumours has significantly } \\
\text { reduced risk of recurrences (HR } 0.71, p \\
=0.021 \text { ). The } 5 \text {-year DFS and CSS } \\
\text { were better for ERCC1 positive than } \\
\text { negative, and were respectively } 62 \% \\
\text { vs } 49 \% \text { and } 70 \% \text { vs } 59 \% \text {. However, } \\
\text { there was no important outcomes of } \\
\text { adjuvant cisplatin-based } \\
\text { chemotherapy by ERCC1 status. }\end{array}$ & (1) & $\begin{array}{l}\text { Study cohort had } 432 \text { patients and } 308 \text { of tumours expressed } \\
\text { ERCC1. Staining was conducted using Abcam }{ }^{\circledR} \text { mouse } \\
\text { monoclonal antibody and expression of ERCC1was evaluated } \\
\text { by } 2 \text { pathologists. Chi-square test was made to assessed } \\
\text { differences between ERCC1 expression. All analyses were } \\
\text { performed with STATA }{ }^{\circledR} \text {, version } 13.1 \text {. } \\
\text { Primary tumour samples collected at RC, cells were lysed and } \\
\text { total RNA was extracted with Qiagen }{ }^{\circledR} \text { kit. ERCC1 mRNA } \\
\text { expression was measured by RNA sequencing and confirmed } \\
\text { by qPCR using TaqMan }{ }^{\circledR} \text { gene expression assays. }\end{array}$ & $\begin{array}{l}\text { UCB cell } \\
\text { lines } \\
\text { in vitro }(n \\
=432)\end{array}$ & No data & [22] \\
\hline $\begin{array}{l}\text { TUMOR } \\
\text { SUPPRESSOR } \\
\text { P53 }\end{array}$ & TP53 gene & $\begin{array}{l}\text { Diagnostic } \\
\quad \text { (as a } \\
\text { complementary } \\
\text { tool) and } \\
\text { surveillance }\end{array}$ & $\begin{array}{c}54 \%(56 / 103) \text { of } \\
\text { cases had TP53 } \\
\text { mutations. } \\
\text { Ta }=40 \% \\
\text { T1 }=52 \% \\
\text { T2 }=80 \% \\
\text { CIS }=55 \% \\
\text { LG }=34 \% \\
\text { HG }=62 \%\end{array}$ & $\begin{array}{l}\text { High risk of malignancy-significant } \\
\text { difference of TP53 mutations } \\
\text { according to tumour stage }(p=0.005) \\
\text { and to cellular grade }(p<0.001)\end{array}$ & No & $\begin{array}{l}\text { Sample collection of urine and tumours from } 103 \text { patients. } \\
\text { Extraction of mRNA was made by Micro mRNA Purification } \\
\text { Kit. Then Verso Kit }{ }^{\circledR} \text { were used to reverse transcription, } \\
\text { amplification was performed by PCR PrimeStar }{ }^{\circledR} \text {. FASAY } \\
\text { assay was used to detect TP53 mutations in tumour tissues } \\
\text { and urinary cells. Statistical test was performed using SPSS } \\
\text { software }{ }^{\circledR}, \text { version } 17 .\end{array}$ & $\begin{array}{l}\text { Primary } \\
\text { bladder } \\
\text { tumours } \\
\text { and } \\
\text { associated } \\
\text { urine }(n= \\
103)\end{array}$ & $\begin{array}{l}\text { Sensitivity } \\
=34 \% \\
\text { Specificity } \\
=87 \% \\
\text { PPV }=0.76 \\
\text { NPV }= \\
0.53\end{array}$ & [23] \\
\hline
\end{tabular}


Table 1. Cont.

\begin{tabular}{|c|c|c|c|c|c|c|c|c|c|}
\hline $\begin{array}{l}\text { Protein } \\
\text { Name }\end{array}$ & $\begin{array}{c}\text { Gene } \\
\text { Symbol }\end{array}$ & Purpose & $\begin{array}{l}\text { Diagnostic } \\
\text { Value }\end{array}$ & Prognostic Value & $\begin{array}{l}\text { FDA } \\
\text { Approv }\end{array}$ & Method & $\begin{array}{l}\text { Samples } \\
\text { Used (No. } \\
\text { Patients) }\end{array}$ & $\begin{array}{l}\text { Predicitive } \\
\text { Capacity }\end{array}$ & Reference \\
\hline \multirow[t]{2}{*}{$\begin{array}{l}\text { FIBROBLAST } \\
\text { GROWTH } \\
\text { FACTOR } \\
\text { RECEPTOR } \\
3 \\
3\end{array}$} & \multirow[t]{2}{*}{$\begin{array}{l}\text { FGFR3 } \\
\text { gene }\end{array}$} & \multirow{2}{*}{$\begin{array}{l}\text { Diagnostic } \\
\text { (as a } \\
\text { complementary } \\
\text { tool) and } \\
\text { surveillance } \\
\end{array}$} & \multirow{2}{*}{$\begin{array}{c}36 \%(37 / 103) \text { of } \\
\text { cases had } \\
\text { FGFR3 } \\
\text { mutations. Ta }= \\
55 \% \\
\text { T1 }=29 \% \\
\text { T2 }=19 \% \\
\text { CIS }=10 \% \\
\text { LG }=62 \% \\
\text { HG }=26 \%\end{array}$} & \multirow{2}{*}{$\begin{array}{l}\text { Low risk of malignancy-negative } \\
\text { association of FGFR3 mutations based } \\
\text { on tumour stage }(p=0.002) \text { and } \\
\text { cellular grade }(p<0.001) \text { [23]. Low } \\
\text { level of FGFR3 expression is an } \\
\text { independent predictor of cancer } \\
\text { progression and is associated with HG } \\
\text { tumours [24]. }\end{array}$} & \multirow[t]{2}{*}{ No* } & \multirow[t]{2}{*}{$\begin{array}{l}\text { Sample collection of urine and tumours from } 103 \text { patients. } \\
\text { Extraction of genomic DNA was performed by QIAamp Viral } \\
\text { RNA }{ }^{\circledR} \text { Mini kit. Multiplex PCR Kit were used to amplification. } \\
\text { Snapshot }{ }^{\circledR} \text { kit was used to detect FGFR3 eight most frequent } \\
\text { mutations hotspots in tumour tissues and urinary cells (two } \\
\text { independent analysis were carried out). Statistical test was } \\
\text { performed using SPSS software }{ }^{\circledR}, \text { version } 17 .\end{array}$} & \multirow[t]{2}{*}{$\begin{array}{l}\text { Primary } \\
\text { bladder } \\
\text { tumours } \\
\quad \text { and } \\
\text { associated } \\
\text { urine }(n= \\
103)\end{array}$} & $\begin{array}{l}\text { Sensitivity } \\
\quad=43 \% \\
\text { Specificity } \\
\quad=98 \% \\
\text { PPV }=0.94 \\
\text { NPV }=0.76\end{array}$ & [23] \\
\hline & & & & & & & & $\begin{array}{l}\text { Sensitivity } \\
=97.6 \% \\
\text { Specificity } \\
=84.8 \% \\
\text { AUC }= \\
0.96 \\
\text { NPV }= \\
0.996(1)\end{array}$ & [25] \\
\hline \multirow[t]{2}{*}{$\begin{array}{l}\text { TUMOR- } \\
\text { ASSOCIATED } \\
\text { TRYPSIN } \\
\text { INHIBITOR }\end{array}$} & \multirow[t]{2}{*}{$\begin{array}{l}\text { SPINK1 } \\
\text { gene }\end{array}$} & \multirow[t]{2}{*}{$\begin{array}{l}\text { Diagnostic } \\
\text { and } \\
\text { surveillance }\end{array}$} & \multirow{2}{*}{$\begin{array}{c}49.1 \%(54 / 110) \\
\text { of cases had } \\
\text { TATI expression. } \\
\text { Stage }<\mathrm{T} 2= \\
66.7 \% \\
\text { Stage } \geq \mathrm{T} 2= \\
44.9 \% \mathrm{LG}= \\
76.2 \% \mathrm{HG}= \\
44.9 \%\end{array}$} & \multirow{2}{*}{$\begin{array}{l}\text { Low risk of malignancy-negative } \\
\text { association of TATI expression was } \\
\text { positively correlated based on tumour } \\
\text { stage }(p=0.048) \text { and poor } \\
\text { differentiation }(p=0.013) \text {. Significant } \\
\text { differences were observed between } \\
\text { TATI-positive and negative specimens } \\
\text { in PFS and OS (Log-rank test, } p=0.003 \text {, } \\
\text { 0.003). In a group of patients with BC } \\
\text { undergoing RC TATI expression was } \\
\text { independent protective factor. } \\
\text { Moreover, TATI expression could } \\
\text { enhance prognostic value of p53. }\end{array}$} & \multirow[t]{2}{*}{ No } & $\begin{array}{l}\text { Study cohort had } 110 \text { patients and } 54 \text { of tumours, undergone } \\
\text { RC, expressed TATI. Staining was conducted using Abcam }{ }^{\circledR} \\
\text { anti-TATI monoclonal antibody and expression of TATI was } \\
\text { evaluated by } 2 \text { pathologists. Proportion of immune-positive } \\
\text { cells and their staining intensity was scored in two scales and } \\
\text { used to evaluation of TATI expression. All analyses were } \\
\text { performed with SPSS software, version } 21 \text {. }\end{array}$ & $\begin{array}{l}\text { Tissue } \\
\text { microarrays } \\
\text { from UCB } \\
(n=110)\end{array}$ & No data & [26] \\
\hline & & & & & & $\begin{array}{l}\text { Study cohort consisted of } 160 \text { patients, divided into } 3 \text { groups. } \\
\text { Group } 1 \text { had } 80 \text { primary HG UBC. Group } 2 \text { of } 40 \text { healthy } \\
\text { volunteers and group } 3 \text { of } 40 \text { benign UBC. TATI was measured } \\
\text { using a radioimmunoassay according to the manufacturer's } \\
\text { instructions (Orion Diagnostica). Analyses were performer } \\
\text { with STATA }{ }^{\circledR} \text {, statistical software, version } 6.0\end{array}$ & $\begin{array}{l}\text { Urine }(n= \\
160)\end{array}$ & $\begin{array}{l}\text { Sensitivity } \\
=85.7 \% \\
\text { Specificity } \\
=77.5 \%\end{array}$ & [27] \\
\hline
\end{tabular}




\subsection{Excision Repair Cross-Complementation 1 (ERCC1)}

The nucleotide excision repair (NER) pathway is important for the protection of genomic stability and for the removal of platinum-induced DNA adducts and cisplatin resistance [28,29]. The key molecules in this pathway belong to the excision repair cross-complementing group 1 (ERCC1) [30].

The ERCC1 role is detecting, repairing and rate-limiting the interstrand cross-links in DNA [31]. Therefore, this enzyme may be representative for the crucial DNA damage repair ability of the cell [32,33]. In a group of patients treated with a surgical resection, ERCC1 as the DNA repair protein may also be engaged in weakening the malignancy of tumors by reducing the amount of mutations. Moreover, genetic testing of ERCC1 expression levels could personalize the chemotherapy by selecting the patients who would benefit from platinum-based chemotherapy. A variety of tumors, including bladder tumors, show that the ERCC1 level is strongly associated with cisplatin resistance [34].

One of the first reports in the literature presenting the impact of ERCC1 expression on the survival of oncologically treated patients was the study of George R. Simon. In 2005, Simon's analysis included 51 patients who were operated on for non-small cell lung cancer and determined their ERCC1 expression. The median survival in the ERCC1 positive expression group was found to be significantly longer-94.9 months compared with 35.5 months in the negative ERCC1 group. The conclusions were that the ERCC1 expression might be an independent prognostic factor for survival in lung cancer [32].

In 2006, Olaussen's work on a large group of patients was published, which included the results of a study of 761 patients after radical lung cancer surgery. The goal was to identify a group of patients who might take an advantage from adjuvant treatment. The study showed that the benefit of adjuvant chemotherapy concerned the patients with a negative ERCC1 expression. An interesting finding was that in the group that did not receive chemotherapy but was only treated surgically, patients with a positive ERCC1 expression had a longer survival compared with those with a negative ERCC1 expression [31].

In advanced non-small cell lung cancer, the ERCC1 expression has a significant prognostic value and its high level is associated with a longer survival in patients who do not receive chemotherapy after a complete resection [31,32]. Piljić et al. indicated that the ERCC1 expression in all stages of lung carcinoma has a great value in monitoring patients receiving chemotherapy based on platinum [35]. $\mathrm{Li}$ et al. indicated that in a group of patients with advanced non-small cell lung cancer, ERCC1-negative had better progression-free survival (PFS) $(p=0.016)$ and overall survival (OS) $(p=0.030)$ in comparison with positive patients [36].

The value of ERCC1 has also been confirmed in other cancers. ERCC1 is one of the most frequent in $84 \%$ or even more of colon cancers, and reductions of a DNA repair gene has been observed [37,38]. In $40 \%$ of the crypts within $10 \mathrm{~cm}$ on each side of colonic adenocarcinomas, ERCC 1 was found to be deficient [37]. The literature data presented above show a significant relationship between the ERCC1 expression and survival in different types of cancer.

In 2012, Sun [39] analyzed 93 patients with BC who underwent radical cystectomy and they demonstrated that ERCC1 can be used as a prognostic and predictive biomarker in this group. An ERCC1-positive expression was found in $58 \%$ of patients, and the study group was divided into those who received additional adjuvant chemotherapy and those without chemotherapy. It was found that patients after radical cystectomy without adjuvant chemotherapy with a high ERCC1 expression have a significantly longer five-year survival than those with a low expression, $84 \%$ to $49 \%$, respectively. It has also been reported that ERCC1-negative patients potentially may benefit from adjuvant chemotherapy.

Klatte and colleagues [22] presented the work assessing ERCC1 as a prognostic and predictive biomarker of bladder cancer after cystectomy. In a group of 432 patients, a positive expression was found in $71 \%$ of patients. Patients with an ERCC1-positive expression had a significantly better five-year disease-free survival (DFS) than those with an ERCC1-negative expression, $62 \%$ to $49 \%$, and cancer-specific survival (CSS), 70\% to 59\%, respectively. In the ERCC1-positive group, the risk of bladder cancer (BC) recurrence and death due to BC was 30\% lower. Patients undergoing radical 
cystectomy with an ERCC1-positive expression had better survival values than those with a negative expression. Therefore, ERCC1 may be an independent prognostic marker for bladder cancer.

Similar conclusions were made in Hemdan's report. They evaluated a group of 244 patients who underwent radical cystectomy or neoadjuvant chemotherapy and radical cystectomy. Negative ERCC1 correlated with a worse overall survival in the group with only surgical treatment. It was noted that neoadjuvant chemotherapy would benefit mainly patients with an ERCC1-negative expression, while for those who were ERCC1-positive, the influence was minimal [40].

Another meta-analysis was published by Urun [41], performed on 1425 patients from 13 studies, and patients with an ERCC1-positive expression constituted $24-76 \%$ of the examined populations. The role of ERCC1 as a prognostic factor of survival was assessed in patients with advanced bladder cancer treated with platinum-based chemotherapy. The conclusions were that a positive ERCC1 expression is not significantly related to overall survival, but has a significant impact on worse progression-free survival, and may be an indicator of worse survival in patients with advanced bladder cancer, but large prospective studies are needed to consider ERCC1 as a prognostic marker in patients with advanced bladder cancer.

Sakano [42] suggested that, in the group of patients with bladder cancer undergoing a combined trimodality approach, the disease-specific survival might be predicted by the expression of ERCC1 and XRCC1. A positive expression of these molecules was connected with better disease-specific survival rates but further research is needed to confirm these results.

Analyzing the previous studies, gives controversial information about predicting the prognostic role of ERCC1 in the treatment of advanced bladder cancer. In 2018, Eldehna [34] conducted a descriptive study on 80 patients with muscle-invasive bladder cancer (stages T2-T4a) who received platinum-based chemotherapy. The results of their research showed a significant relationship between a platinum-based treatment response and the ERCC1 expression in bladder cancer tissue samples $(p=0.013)$. It was an indicative association between a negative immuno-expression and more favorable outcome but no difference between the ERCC1 expression and mean overall survival or progression-free survival in different immune-expression levels in patients was apparent. Therefore, ERCC1 may be a potential predictive but not prognostic marker and for this reason, genetic testing could personalize chemotherapy by selecting the patients who would benefit from a platinum-based treatment in bladder cancer.

In summary, ERCC1-positive tumors were associated with better prognosis in cases without chemotherapies. However, in cases with chemotherapies, ERCC1-negative tumors were associated with a better outcome.

The most possible explanation for the above scenario seems related to the function of this enzyme, which appears crucial in the DNA damage repair ability of the cell. The above DNA repair, related to the ERCC1 activity, is, however, non-beneficial for patients treated with chemotherapy, potentially leading to an "antichemotherapeutic" activity.

\subsection{Tumour Protein p53 (TP53)}

The common oncosuppressor gene mutated in all human cancers and the most frequently mutated gene in MIBC is the tumor protein p53 (TP53) [43]. Genomic integrity and stability are maintained by TP53 via triggering a cell-cycle arrest, apoptosis, autophagy and DNA repair. Mutant p53 proteins silence the autophagy related gene (ATG) which affects the autophagic flow, and therefore suppresses regulation to the autophagic vesicles formation and their fusion with lysosomes [44]. Additionally, p53 preferentially binds to the AMPK $\alpha$ subunit and inhibits the AMPK activation. Mutp53s become oncogenic via the activation of AMPK [45].

Bladder carcinogenesis is closely associated with tumor suppressor dysfunction and the inactivation of TP53 [46]. Therefore, p53 has been studied as a marker of urothelial cell carcinoma recurrence and progression. 
Cheap and simple methods to detect the abnormal function of p53 is immunohistochemistry staining (IHC). The short half-life of wild-type p53 prevents its intra-nuclear accumulation [47].

Increased p53 accumulation in the cell nucleus is a result of TP53 mutations.

Immunohistochemical patterns of TP53 mutations are strongly associated with the progression of urothelial cell carcinoma. Plenty of data illustrate that from non-missense mutations (i.e., nonsense, insertion and deletion) to wild-type TP53, the expression of p53's IHC increases. That promotes the grow up of an invasive phenotype of bladder cancer [48]. The high expression of $\mathrm{p} 53$ has been associated with features of tumor aggressiveness and correlated with poor oncological outcomes [43,49]. Therefore, this protein level was higher in more advanced bladder cancer [50,51]. Plenty of studies have indicated that p53 can be useful to assess the level of progress and to prognose urothelial cell carcinoma [49,51].

However, Ciccasese and colleagues [52] published a study with a contradictory opinion. In their opinion, the single p53 marker is not good enough as a prognostic marker of MIBC.

Moreover, the most aggressive T1 high-grade cancers appear to be also associated with the expression of this protein. The progression from T1 NMIBC to T1HG can be predicted by a p53 overexpression [53].

Authors [51] collected data from 70 patients and showed that $16 \%$ of patients with low-grade and $91 \%$ of patients with high-grade lesions were p53-positive. There was $33 \%$ positivity in Tis, $55 \%$ in $\mathrm{T} 1,72 \%$ in $\mathrm{T} 2$ and 100\% in T3a and T3b. These results indicated a strong intensification of p53 staining- $94.6 \%$ of high-grade and $5.4 \%$ of low-grade tumors. Moreover, the p53 accumulation in the nucleus, in a group treated with radical cystectomy and in other MIBCs, has a prognostic value [54].

Another study showed that an aggressive tumor phenotype is strongly associated with the overexpression of p53 [43]. MIBC and CIS correlated with a high level of TP53 deletion and mutation [55]. According to the TCGA cohort data [4], 89\% of MIBCs have an inactivated TP53 cell-cycle pathway, with TP53 mutations in 48\%. Bladder epithelial cells become malignant by the TP53/RB1 pathway or the FGFR3/RAS pathway [55].

\subsection{Fibroblast Growth Factor Receptor 3 (FGFR3)}

Fibroblast growth factor receptor 3 (FGFR3) alternations are associated with urothelial cell carcinoma pathogenesis [56,57]. FGFR3 is activated by the mutation or overexpression in many bladder tumors at any stage, but is predominantly active in low-grade NMIBCs [58,59]. Higher levels of FGFR3 expression were observed in low-grade, non-invasive tumors and recurrent non-invasive tumors than in invasive and non-invasive high-grade carcinoma [57].

This marker is associated with a lower chance of progression to a muscle-invasive disease and it is like a hallmark of the low-grade pathway. FGFR3 alternations occur mainly in non-invasive tumors $[59,60]$, specifically in the luminal-papillary subtype $(35 \%)$, which has the best overall survival and is characterized by a papillary morphology $[59,61]$. Moreover, many studies indicated that FGFR3 mutation and the risk of progression are an inverse interaction. Therefore, patients with MIBC and the FGFR3 mutation have better survival rates [62]. Another study suggests that also the progression in pT1 tumors is in negative correlation with the FGFR3 mutation [63]. Many studies confirm that FGFR3 mutations correlate with an overall benign effect $[59,63,64]$. Moreover, in the risk stratification, surveillance and diagnosis of low- or high-risk NMIBC patients, FGFR3 mutations combined with the promoter hyper-methylation of HS3ST2, SEPTIN9 and SLIT2 have shown $97.6 \%$ sensitivity and $84.8 \%$ specificity (Table 1) [25]. The presence of the FGFR3 mutation in urine is observed not only in low-grade tumors but it also seems to be associated with future recurrence $[65,66]$.

FGFR3 is involved in tumorigenesis in $\sim 40 \%$ of invasive bladder cancer and in the majority $(\sim 80 \%)$ of low-grade non-invasive (stage Ta) bladder cancers [59]. Tomlinson et al. observed an FGFR3 overexpression in nearly $40 \%$ of MIBC, whereas mutations occurred in $21 \%$ of MIBC [67]. Sung [56] observed that an FGFR3 overexpression results in the worst overall survival and disease-free survival 
in a group of patients with adjuvant chemotherapy. In a group without this treatment, no prognostic significance was observed.

High levels of FGFR3- and PIK3CA-mutated DNA in urine can be useful in predicting later metastasis and progression in NMIBC [68]. Choi et al. indicated that FGFR3 mutations are characteristic for the luminal type of MIBC [69]. In conclusion, FGFR3 may be an important therapeutic target in both non-invasive and invasive BC [58,59].

In the results of their research, Beukers [60] confirmed that mutations in FGFR3 were more often observed in low-grade tumors and the papillary urothelial neoplasm of low malignant potential (PUNLMP) + G1 (61.9\%) than in high-grade tumors G2 + G3, at 17.2\%. It was also observed that FGFR3 mutations were more frequent in non-invasive tumors' Tis and Ta stages, at $53.4 \%$, than in the invasive stages of T1 and T2, at $12.5 \%$. Mutations correlated with a better survival rate and occurred in a higher level in non-invasive than in advanced diseases, and these values for TaG1, TaG2, TaG3 + T1 and T2 were $67.3 \%, 43.3 \%, 20.3 \%$ and $6.3 \%$ respectively. It was also noticed, but with no statistically significant correlation, that FGFR3 mutations increase the possibility of disease recurrence [70]. Hosen et al. showed that FGFR3 mutations have no significant influence on patient survival and that in the Ta, T1, TaG1 and TaG2 diseases, it did not significantly predict the recurrence rate [70].

Knowles et al. also demonstrated that the FGFR3/HRAS mutation was often present in the development of urothelial hyperplasia, which can progress to non-invasive papillary tumors with high recurrence rates via the FGFR3/RAS pathway [8].

Van Rhijn [63] conducted a study on a group of 132 patients with primary pT1 bladder cancer. The diagnosis was confirmed after a uropathologist review of the slides. FGFR3 mutations were identified by a SNaPshot ${ }^{\circledR}$ analysis in 37 of 132 pT1 bladder cancer cases $(28 \%)$ and an altered P53 expression was determined by standard immunohistochemistry in 71 of them (54\%). Both molecular alternations were observed in $8 \%$ of patients. In predicting progression, carcinoma in situ and the status of the FGFR3 mutation were significant but TP53 was not. It was also mentioned that the presence of $F G F R 3$ mutations helps to identify patients who have a better disease prognosis because the FGFR 3 mutation occurs with lower grade and altered TP53 with high-grade pT1 bladder cancer.

Hernández and colleagues [64] analyzed 772 samples from patients with bladder tumors reviewed by expert pathologists. Their results indicated that FGFR3 mutations were more frequently observed in neoplasms with low malignant potential, at $77 \%$, and in tumors TaG1, at $61 \%$, and TaG2, at $58 \%$, than in tumors TaG3, at 34\%, and T1G3, at 17\%. They also confirm the association between superficial tumors and a high presence of recurrence. Nevertheless, a significant increase risk was observed only in the group of patients with TaG1 tumors. In this study, another positive correlation of good prognosis and occupancy of FGFR3 was confirmed.

Kompier [71] performed a study on 118 patients with primary and recurrent NMI-BC. They analyzed the FGFR3 mutation status in the disease process. The analyzed group had 2133 cystoscopies done within the median follow-up of 8.8 years and 414 tumor recurrences developed in 80 patients. FGFR3 mutations were equally distributed in the recurrences and the primary tumors (63\%). Different tumors may have a variety of FGFR3 mutations types. Mutant or wild-type primary tumors had a similar risk of recurrence but in $81 \%$ of recurrences, a mutation was found. In this group, recurrences developed after 10 years and, in comparison with the wild-type primary tumor, occurred in a lower grade and stage.

Therefore, a follow-up surveillance based on the presence of the FGFR3 mutation analysis with the reduction in the number of cystoscopies may be considered [71].

In another study, Kompier and colleagues [72] confirmed the correlations between a low risk of progression and better disease-specific survival in the primary mutant FGFR3 tumor and worse prognosis in the group of patients with an overexpression of $\mathrm{p} 53$.

Williams et al. found that in the selection of patients for the FGFR-targeted therapy, the existence of a fusion protein, which indicates other classes of mutations in a group with a high FGFR3 expression, may be helpful [58]. 
The study [73] shows that FGFR3 mutations may influence tumorigenesis by regulating an acute inflammatory response which via the immune cells destroys the tumor cells. Therefore, there may be potential treatment strategy for the early stage of FGFR3-mutated or overexpressed BC based on the synchronal inhibition of FGFR3 and the immune modulators.

Noel [23] conducted a pilot study to assess the TP53 and FGFR3 mutations in urine and tumoral tissues samples that had been collected from 103 BC patients. Mutations in TP53 were detected in $54 \%$ of the 103 bladder tumors and the distribution increased with the cellular grade $(p<0.001)$. The TP53 mutation presented $34 \%$ of low- grade (LG) and $62 \%$ of high- grade (HG) tumors. The potential prognostic value of TP53 may indicate a significant difference in the tumor stage $(p=0.005)$. The specificity was $87 \%$, with the positive predictive value (PPV) $76 \%$ and with the negative predictive value (NPV) 53\%. However, the sensitivity in the urine test was only $34 \%$ (Table 1 ).

In $36 \%$ of analyzed tumors, FRFG3 mutations were identified and their distribution decreased with the cellular grade $(p<0.001)$. They occurred in $62 \%$ of LG tumors versus $26 \%$ in HG. A negative correlation was also between the FGFR3 mutations and tumor stage $(p=0.002)$. All predictive capacities were better for the FGFR3 than for the TP53 mutations measured in this study, the sensitivity was $43 \%$ and the specificity was $98 \%$, with the PPV $94 \%$ and the NPV 76\% (Table 1) [23].

The results showed that TP53/FGFR3 could be useful as a complementary tool in diagnosis but could not replace urine cytology. The tumor stage and grade are strongly correlated with the FGFR3 and TP53 mutations, which are in "mirror distribution" [23].

Kang [24] enrolled 120 patients with primary PT1 BC and examined in this subgroup the utility of expression levels and mutation status of FGFR3 as a prognostic marker. In this study, $40 \%$ of patients had FGFR3 mutations and those patients also had significantly higher levels of the FGFR3 expression compared with the FGFR3 wild-type BC $(p<0.001)$. The mutation status was not associated with cancer progression, but a low level of FGFR3 correlated with cancer progression and HG tumors ( $p=0.001$ and $p=0.006$ ). Therefore, the FGFR3 expression level was, in the multivariate analysis, identified as an independent predictor of cancer progression (Table 1). Significant was also the correlation between the FGFR3 mutation and a low tumor grade. In tumor recurrence, both the FGFR3 mutation status and mRNA expression level revealed no significant differences ( $p=0.264$ and $p=0.856$, respectively).

In conclusion, FGFR3 may be used as a urine-based assay in the detection of primary tumors, recurrences, for prognosis and targeted therapies.

\subsection{Tumor-Associated Trypsin Inhibitor (TATI)}

TATI is a peptide produced at lower concentrations in many healthy tissues, especially in the gastrointestinal and urogenital tracts but also in the gall bladder, kidney and breast.

It occurs in high concentrations by several tumors such as gynecologic, gastrointestinal, urologic, lung, breast, head and neck cancers [74-79]. An increased level of TATI is also observed in renal failure and in dialysis patients because this peptide is cleared from the circulation by renal excretion. Therefore, a low glomerular filtration rate correlates with an increase in TATI [80].

TATI is connected with tumor aggression because it appears in the co-expression with tumor-associated trypsin, which participates in moderating tumor-associated protease cascades [81].

TATI is produced at high concentrations by mucinous ovarian tumors, and was initially isolated from the urine of a patient with ovarian cancer. The most useful clinical application of this peptide is observed in the detection of ovarian tumors: benign and malignant [82].

TATI occurs in a high level also in other benign and malignant diseases. Pancreatitis and strong acute phase reactions (when serum CRP is clearly increased (>90 mg/L)) such as severe injury or inflammatory diseases trigger a TATI expression. This fact is a limiting factor of the use of TATI as a tumor marker but it does not invalidate this peptide [83]. In cancers, an increased TATI concentration is associated not only with tumor production but also acute phase reactions caused by tissue destruction during cancer invasion [81]. 
Serum values of TATI have also been used in patients with muscle-invasive and metastatic transitional cell carcinoma, to monitor the response to therapy. In 1996, Pectasides [74] suggested that TATI might be potentially useful in monitoring the efficacy of treatment in transitional cell carcinoma of the bladder. Significantly modified values of TATI were observed in metastatic diseases, in patients with complete or partial remission and non-responders. An important increase in TATI in T2-T4-N0M0 tumors were in the non-responders.

Kelloniemi et al. showed that for the identification group of patients with adverse prognosis in transitional cell carcinoma serum, TATI might be an independent prognostic factor [84].

Shariat [85] indicated that TATI is more specific than NMP22 for the detection of bladder transitional cell carcinoma (TCC). They showed also that higher levels of TATI were in TCC patients and in more invasive stages.

In 2006, Hotakainen [86] reported that a TATI expression was observed in all non-invasive tumors and benign tissues, but the expression was lower in the muscle-invasive tumors. Therefore, they concluded that the TATI expression decreases with the rising stage and grade of the tumor in bladder cancer. Therefore, as for TATI, Shariat [85] showed that higher levels of TATI were associated with more invasive TCC but Hotakainen [86] revealed that the TATI expression decreases with the rising stage. The discrepancy between the results of the studies is most probably related to the different populations of bladder cancer patients. The study by Shariat [85], comprised of 153 consecutive patients who had a history of previous, histologically confirmed bladder cancer, without evidence of muscle invasion (stages Ta, T1 and/or CIS). In the Hotakainen $(n=28)$ group, the individuals were affected with both non-invasive and invasive BC.

Gkialas [27] showed that TATI was significantly more sensitive in stage Ta (80\%) than was CYFRA 21-1 (32\%), UBC (12\%) and cytology (20\%). TATI was different also between stages and was more sensitive compared with other tumor markers for stage T1.

Patschan and colleagues [87] confirmed that the TATI level shows a positive correlation with low-stage tumors and the favorable differentiation of bladder cancer. They also showed in univariate analyses, that a decreased level of TATI was associated with high recurrences and cancer-specific mortality.

Liu [26] made a similar conclusion that a decrease in the TATI expression correlated with a more advanced disease. Moreover, in the progression of bladder cancer, the prognostic value of a p53 overexpression can be enhanced by TATI.

Bladder cancer management is one of the most complex and expensive in uro-oncology. An ideal biomarker of the future should be potentially able to detect the disease before its clinical manifestation. The BC mortality rate is another major reason to obtain a similar screening method to that available in other cancers, i.e., prostate and colon.

Currently, flexible cystoscopy remains a mainstay in BC diagnosis and it appears unlikely that available biomarkers would quickly rule out this standard approach in clinical practice. On the other hand, developing markers showing a correlation with cancer aggressiveness and being able to distinguish between aggressive and non-aggressive tumors appears of utmost clinical importance. Hopefully, one of the discussed markers might become helpful in patients' selection for an appropriate treatment plan and personalized cancer medicine. The prospective studies on a larger group of individuals are still needed in order to obtain additional prognostic information that will improve results, reduce adverse effects and in future allow us to individualize bladder cancer treatments.

Author Contributions: All authors made substantial contributions to this work; acquisition and interpretation of data by online search, M.S., M.M.; draft and supervision of the work, M.S.; revision of the work, M.S. All authors have approved the final version and agree to be personally accountable for the author's own contributions.

Funding: This research received no external funding.

Conflicts of Interest: The authors declare no conflict of interest. 


\section{Abbreviations}

$\begin{array}{ll}\text { AUC } & \text { Area under the curve } \\ \text { BC } & \text { Bladder cancer } \\ \text { BCG } & \text { Bacille Calmette-Guérin } \\ \text { CIS } & \text { Carcinoma in situ } \\ \text { CK } & \text { Cytokeratin } \\ \text { CSS } & \text { Cancer-specific survival } \\ \text { CYFRA 21.1 } & \text { Cytokeratin fragment 21.1 } \\ \text { DFS } & \text { Disease-free survival } \\ \text { ERCC1 } & \text { Excision repair cross-complementing group 1 } \\ \text { HG } & \text { High grade } \\ \text { IHC } & \text { Immunohistochemistry staining } \\ \text { LG } & \text { Low grade } \\ \text { MIBC } & \text { Muscle-invasive bladder cancer } \\ \text { NMIBC } & \text { Non-muscle invasive bladder cancer } \\ \text { NPV } & \text { Negative predictive value } \\ \text { OS } & \text { Overall survival } \\ \text { PFS } & \text { Progression-free survival } \\ \text { PPV } & \text { Positive predictive value } \\ \text { PUNLMP } & \text { Papillary urothelial neoplasm of low malignant potential } \\ \text { TURBT } & \text { Transurethral resection of bladder tumor } \\ \text { UBC } & \text { Urothelial bladder cancer } \\ \text { UC } & \text { Urothelial carcinoma } \\ & \end{array}$

\section{References}

1. Siegel, R.L.; Miller, K.D.; Jemal, A. Cancer statistics, 2020. CA A Cancer J. Clin. 2020, 70, 7-30. [CrossRef]

2. Antoni, S.; Ferlay, J.; Soerjomataram, I.; Znaor, A.; Jemal, A.; Bray, F. Bladder cancer incidence and mortality: A global overview and recent trends. Eur. Urol. 2017, 71, 96-108. [CrossRef] [PubMed]

3. Sanli, O.; Dobruch, J.; Knowles, M.A.; Burger, M.; Alemozaffar, M.; Nielsen, M.E.; Lotan, Y. Bladder cancer. Nat. Rev. Dis. Primers 2017, 3, 1-19. [CrossRef] [PubMed]

4. Robertson, A.G.; Kim, J.; Al-Ahmadie, H.; Bellmunt, J.; Guo, G.; Cherniack, A.D.; Hinoue, T.; Laird, P.W.; Hoadley, K.A.; Akbani, R.; et al. Comprehensive molecular characterization of muscle-invasive bladder cancer. Cell 2017, 171, 540-556. [CrossRef] [PubMed]

5. Humphrey, P.A.; Moch, H.; Cubilla, A.L.; Ulbright, T.M.; Reuter, V.E. The 2016 WHO classification of tumours of the urinary system and male genital organs_Part B: Prostate and bladder tumours. Eur. Urol. 2016, 70, 106-119. [CrossRef]

6. Czerniak, B.; Dinney, C.; McConkey, D. Origins of bladder cancer. Annu. Rev. Pathol. Mech. Dis. 2016, 11, 149-174. [CrossRef]

7. Babjuk, M.; Burger, M.; Zigeuner, R.; Shariat, S.F.; van Rhijn, B.W.G.; Compérat, E.; Sylvester, R.J.; Kaasinen, E.; Böhle, A.; Redorta, J.P.; et al. EAU Guidelines on Non-Muscle-invasive urothelial carcinoma of the bladder: Update 2013. Eur. Urol. 2013, 64, 639-653. [CrossRef]

8. Knowles, M.A.; Hurst, C.D. Molecular biology of bladder cancer: New insights into pathogenesis and clinical diversity. Nat. Rev. Cancer 2014, 15, 25-41. [CrossRef]

9. Inamura, K. Bladder cancer: New insights into its molecular pathology. Cancers 2018, 10, 100. [CrossRef]

10. Burger, M.; Catto, J.W.F.; Dalbagni, G.; Grossman, H.B.; Herr, H.; Karakiewicz, P.; Kassouf, W.; Kiemeney, L.A.; Vecchia, C.L.; Shariat, S.; et al. Epidemiology and risk factors of urothelial bladder cancer. Eur. Urol. 2013, 63, 234-241. [CrossRef]

11. Woldu, S.L.; Bagrodia, A.; Lotan, Y. Guideline of guidelines: Non-muscle-invasive bladder cancer. BJU Int. 2017, 119, 371-380. [CrossRef] [PubMed]

12. Huang, Y.-L.; Chen, J.; Yan, W.; Zang, D.; Qin, Q.; Deng, A.-M. Diagnostic accuracy of cytokeratin-19 fragment (CYFRA 21-1) for bladder cancer: a systematic review and meta-analysis. Tumor Biol. 2015, 36, 3137-3145. [CrossRef] [PubMed] 
13. Guo, X.-G.; Long, J.-J. Cytokeratin-19 fragment in the diagnosis of bladder carcinoma. Tumor Biol. 2016, 37, 14329-14330. [CrossRef] [PubMed]

14. Kuang, L.I.; Song, W.J.; Qing, H.M.; Yan, S.; Song, F.L. CYFRA21-1 levels could be a biomarker for bladder cancer: A meta-analysis. Genet. Mol. Res. 2015, 14, 3921-3931. [CrossRef]

15. Nisman, B.; Barak, V.; Shapiro, A.; Golijanin, D.; Peretz, T.; Pode, D. Evaluation of urine CYFRA 21-1 for the detection of primary and recurrent bladder carcinoma. Cancer 2002, 94, 2914-2922. [CrossRef]

16. D'Costa, J.J.; Goldsmith, J.C.; Wilson, J.S.; Bryan, R.T.; Ward, D.G. A systematic review of the diagnostic and prognostic value of urinary protein biomarkers in urothelial bladder cancer. Bladder Cancer 2016, 2, 301-317. [CrossRef]

17. Andreadis, C.; Touloupidis, S.; Galaktidou, G.; Kortsaris, A.H.; Boutis, A.; Mouratidou, D. Serum CYFRA 21-1 in patients with invasive bladder cancer and its relevance as a tumor marker during chemotherapy. J. Urol. 2005, 174, 1771-1776. [CrossRef]

18. Nisman, B.; Yutkin, V.; Peretz, T.; Shapiro, A.; Barak, V.; Pode, D. The follow-up of patients with non-muscle-invasive bladder cancer by urine cytology, abdominal ultrasound and urine CYFRA 21-1: A pilot study. Anticancer Res. 2009, 29, 4281-4285.

19. Washino, S.; Hirai, M.; Matsuzaki, A.; Kobayashi, Y. Clinical usefulness of CEA, CA19-9, and CYFRA 21-1 as tumor markers for urothelial bladder carcinoma. Urol. Int. 2011, 87, 420-428. [CrossRef]

20. Dittadi, R.; Barioli, P.; Gion, M.; Mione, R.; Barichello, M.; Capitanio, G.; Cocco, G.; Cazzolato, G.; De Biasi, F.; Praturlon, S.; et al. Standardization of assay for cytokeratin-related tumor marker CYFRA21.1 in urine samples. Clin. Chem. 1996, 42, 1634-1638. [CrossRef]

21. Jeong, S.; Park, Y.; Cho, Y.; Kim, Y.R.; Kim, H.-S. Diagnostic values of urine CYFRA21-1, NMP22, UBC, and FDP for the detection of bladder cancer. Clin. Chim. Acta 2012, 414, 93-100. [CrossRef] [PubMed]

22. Klatte, T.; Seitz, C.; Rink, M.; Rouprêt, M.; Xylinas, E.; Karakiewicz, P.; Susani, M.; Shariat, S.F. ERCC1 as a prognostic and predictive biomarker for urothelial carcinoma of the bladder following radical cystectomy. J. Urol. 2015, 194, 1456-1462. [CrossRef] [PubMed]

23. Noel, N.; Couteau, J.; Maillet, G.; Gobet, F.; D'Aloisio, F.; Minier, C.; Pfister, C. TP53 and FGFR3 Gene mutation assessment in urine: Pilot study for bladder cancer diagnosis. Anticancer Res. 2015, 35, 4915-4921. [PubMed]

24. Kang, H.W.; Kim, Y.-H.; Jeong, P.; Park, C.; Kim, W.T.; Ryu, D.H.; Cha, E.-J.; Ha, Y.-S.; Kim, T.-H.; Kwon, T.G.; et al. Expression levels of FGFR3 as a prognostic marker for the progression of primary pT1 bladder cancer and its association with mutation status. Oncol. Lett. 2017, 14, 3817-3824. [CrossRef] [PubMed]

25. Roperch, J.-P.; Grandchamp, B.; Desgrandchamps, F.; Mongiat-Artus, P.; Ravery, V.; Ouzaid, I.; Roupret, M.; Phe, V.; Ciofu, C.; Tubach, F.; et al. Promoter hypermethylation of HS3ST2, SEPTIN9 and SLIT2 combined with FGFR3 mutations as a sensitive/specific urinary assay for diagnosis and surveillance in patients with low or high-risk non-muscle-invasive bladder cancer. BMC Cancer 2016, 16, 704. [CrossRef]

26. Liu, A.; Xue, Y.; Liu, F.; Tan, H.; Xiong, Q.; Zeng, S.; Zhang, Z.; Gao, X.; Sun, Y.; Xu, C. Prognostic value of the combined expression of tumor-associated trypsin inhibitor (TATI) and p53 in patients with bladder cancer undergoing radical cystectomy. Cancer Biomark. 2019, 26, 281-289. [CrossRef]

27. Gkialas, I.; Papadopoulos, G.; Iordanidou, L.; Stathouros, G.; Tzavara, C.; Gregorakis, A.; Lykourinas, M. Evaluation of urine tumor-associated trypsin inhibitor, CYFRA 21-1, and urinary bladder cancer antigen for detection of high-grade bladder Carcinoma. Urology 2008, 72, 1159-1163. [CrossRef]

28. Rabik, C.A.; Dolan, M.E. Molecular mechanisms of resistance and toxicity associated with platinating agents. Cancer Treat. Rev. 2007, 33, 9-23. [CrossRef]

29. Martin, L.P.; Hamilton, T.C.; Schilder, R.J. Platinum resistance: The role of DNA repair pathways. Clin. Cancer Res. 2008, 14, 1291-1295. [CrossRef]

30. Metzger, R.; Bollschweiler, E.; Hölscher, A.H.; Warnecke-Eberz, U. ERCC1: Impact in multimodality treatment of upper gastrointestinal cancer. Future Oncol. 2010, 6, 1735-1749. [CrossRef]

31. Olaussen, K.A.; Dunant, A.; Fouret, P.; Brambilla, E.; André, F.; Haddad, V.; Taranchon, E.; Filipits, M.; Pirker, R.; Popper, H.H.; et al. DNA repair by ERCC1 in Non-Small-Cell Lung Cancer and Cisplatin-Based Adjuvant Chemotherapy. N. Engl. J. Med. 2006, 355, 983-991. [CrossRef] [PubMed]

32. Simon, G.R.; Sharma, S.; Cantor, A.; Smith, P.; Bepler, G. ERCC1 expression is a predictor of survival in resected patients with non-small cell lung cancer. Chest 2005, 127, 978-983. [CrossRef] [PubMed] 
33. Rosell, R.; Pifarré, A.; Monzó, M.; Astudillo, J.; López-Cabrerizo, M.P.; Calvo, R.; Moreno, I.; Sánchez-Céspedes, M.; Font, A.; Navas-Palacios, J.J. Reduced survival in patients with stage-I non-small-cell lung cancer associated with DNA-replication errors. Int. J. Cancer 1997, 74, 330-334. [CrossRef]

34. Eldehna, W.M.; Fouda, M.M.; Eteba, S.M.; Abdelrahim, M.; Elashry, M.S. Gene expression of excision repair cross-complementation group 1 enzyme as a novel predictive marker in patients receiving platinum-based chemotherapy in advanced bladder cancer. Benha Med. J. 2018, 35, 42-48. [CrossRef]

35. Piljić Burazer, M.; Mladinov, S.; Matana, A.; Kuret, S.; Bezić, J.; Glavina Durdov, M. Low ERCC1 expression is a good predictive marker in lung adenocarcinoma patients receiving chemotherapy based on platinum in all TNM stages-A single-center study. Diagn. Pathol. 2019, 14, 105. [CrossRef]

36. Li, Z.; Qing, Y.; Guan, W.; Li, M.; Peng, Y.; Zhang, S.; Xiong, Y.; Wang, D. Predictive value of APE1, BRCA1, ERCC1 and TUBB3 expression in patients with advanced non-small cell lung cancer (NSCLC) receiving first-line platinum-paclitaxel chemotherapy. Cancer Chemother. Pharmacol. 2014, 74, 777-786. [CrossRef]

37. Facista, A.; Nguyen, H.; Lewis, C.; Prasad, A.R.; Ramsey, L.; Zaitlin, B.; Nfonsam, V.; Krouse, R.S.; Bernstein, H.; Payne, C.M.; et al. Deficient expression of DNA repair enzymes in early progression to sporadic colon cancer. Genome Integr. 2012, 3, 3. [CrossRef]

38. Smith, D.H.; Fiehn, A.-M.K.; Fogh, L.; Christensen, I.J.; Hansen, T.P.; Stenvang, J.; Nielsen, H.J.; Nielsen, K.V.; Hasselby, J.P.; Brünner, N.; et al. Measuring ERCC1 protein expression in cancer specimens: Validation of a novel antibody. Sci. Rep. 2014, 4, 4313. [CrossRef]

39. Sun, J.-M.; Sung, J.-Y.; Park, S.H.; Kwon, G.Y.; Jeong, B.C.; Seo, S.I.; Jeon, S.S.; Lee, H.M.; Jo, J.; Choi, H.Y.; et al. ERCC1 as a biomarker for bladder cancer patients likely to benefit from adjuvant chemotherapy. BMC Cancer 2012, 12, 187. [CrossRef]

40. Hemdan, T.; Segersten, U.; Malmström, P.-U. 122 ERCC1-negative tumors benefit from neoadjuvant cisplatin-based chemotherapy whereas patients with ERCC1-positive tumors do not-Results from a cystectomy trial database. Eur. Urol. Suppl. 2014, 13, e122. [CrossRef]

41. Urun, Y.; Leow, J.J.; Fay, A.P.; Albiges, L.; Choueiri, T.K.; Bellmunt, J. ERCC1 as a prognostic factor for survival in patients with advanced urothelial cancer treated with platinum based chemotherapy: A systematic review and meta-analysis. Crit. Rev. Oncol. Hematol. 2017, 120, 120-126. [CrossRef] [PubMed]

42. Sakano, S.; Ogawa, S.; Yamamoto, Y.; Nishijima, J.; Miyachika, Y.; Matsumoto, H.; Hara, T.; Matsuyama, H. ERCC1 and XRCC1 expression predicts survival in bladder cancer patients receiving combined trimodality therapy. Mol. Clin. Oncol. 2013, 1, 403-410. [CrossRef] [PubMed]

43. Chen, L.; Liu, Y.; Zhang, Q.; Zhang, M.; Han, X.; Li, Q.; Xie, T.; Wu, Q.; Sui, X. p53/PCDH17/Beclin-1 proteins as prognostic predictors for urinary bladder cancer. J. Cancer 2019, 10, 6207-6216. [CrossRef] [PubMed]

44. Choundhury, S.; Kolukula, V.; Preet, A.; Albanese, C.; Maria, A. Dissecting the pathways that destabilize mutant p53: The proteasome or autophagy? Cell Cycle 2013, 12, 1022-1029. [CrossRef]

45. Zhou, G.; Wang, J.; Zhao, M.; Xie, T.-X.; Tanaka, N.; Sano, D.; Patel, A.A.; Ward, A.M.; Sandulache, V.C.; Jasser, S.A.; et al. Gain-of-function mutant p53 promotes cell growth and cancer cell metabolism via inhibition of AMPK activation. Mol. Cell 2014, 54, 960-974. [CrossRef]

46. Mitra, A.P. Molecular substratification of bladder cancer: Moving towards individualized patient management. Ther. Adv. Urol. 2016, 8, 215-233. [CrossRef]

47. Ando, K.; Oki, E.; Saeki, H.; Yan, Z.; Tsuda, Y.; Hidaka, G.; Kasagi, Y.; Otsu, H.; Kawano, H.; Kitao, H.; et al. Discrimination of p53 immunohistochemistry-positive tumors by its staining pattern in gastric cancer. Cancer Medicine 2014, 4, 75-83. [CrossRef]

48. Puzio-Kuter, A.M.; Castillo-Martin, M.; Kinkade, C.W.; Wang, X.; Shen, T.H.; Matos, T.; Shen, M.M.; Cordon-Cardo, C.; Abate-Shen, C. Inactivation of p53 and Pten promotes invasive bladder cancer. Genes Dev. 2009, 23, 675-680. [CrossRef]

49. Shariat, S.F.; Chade, D.C.; Karakiewicz, P.I.; Ashfaq, R.; Isbarn, H.; Fradet, Y.; Bastian, P.J.; Nielsen, M.E.; Capitanio, U.; Jeldres, C. Combination of multiple molecular markers can improve prognostication in patients with locally advanced and lymph node positive bladder cancer. J. Urol. 2010, 183, 68-75. [CrossRef]

50. Daizumoto, K.; Yoshimaru, T.; Matsushita, Y.; Fukawa, T.; Uehara, H.; Ono, M.; Komatsu, M.; Kanayama, H.; Katagiri, T. A DDX31/Mutant-p53/EGFR axis promotes multistep progression of muscle-invasive bladder cancer. Cancer Res. 2018, 78, 2233-2247. [CrossRef]

51. Qamar, S.; Inam, Q.A.; Ashraf, S.; Khan, M.S.; Khokhar, M.A.; Awan, N. Prognostic Value of p53 expression intensity in urothelial cancers. J. Coll. Physicians Surg. Pak. 2017, 27, 232-236. [PubMed] 
52. Ciccarese, C.; Massari, F.; Blanca, A.; Tortora, G.; Montironi, R.; Cheng, L.; Scarpelli, M.; Raspollini, M.R.; Vau, N.; Fonseca, J.; et al. Tp53 and its potential therapeutic role as a target in bladder cancer. Expert Opin. Ther. Targets 2017, 21, 401-414. [CrossRef] [PubMed]

53. Du, J.; Wang, S.; Yang, Q.; Chen, Q.; Yao, X. p53 status correlates with the risk of progression in stage T1 bladder cancer: A meta-analysis. World J. Surg. Oncol. 2016, 14, 137. [CrossRef] [PubMed]

54. Shariat, S.F.; Lotan, Y.; Karakiewicz, P.I.; Ashfaq, R.; Isbarn, H.; Fradet, Y.; Bastian, P.J.; Nielsen, M.E.; Capitanio, U.; Jeldres, C.; et al. p53 predictive value for pT1-2 N0 disease at radical cystectomy. J. Urol. 2009, 182, 907-913. [CrossRef] [PubMed]

55. Moch, H.; Cubilla, A.L.; Humphrey, P.A.; Reuter, V.E.; Ulbright, T.M. The 2016 WHO classification of tumours of the urinary system and male genital organs-Part A: Renal, penile, and testicular tumours. Eur. Urol. 2016, 70, 93-105. [CrossRef] [PubMed]

56. Sung, J.-Y.; Sun, J.-M.; Chang Jeong, B.; Il Seo, S.; Soo Jeon, S.; Moo Lee, H.; Choi, H.Y.; Kang, S.Y.; Choi, Y.-L.; Young Kwon, G. FGFR3 overexpression is prognostic of adverse outcome for muscle-invasive bladder carcinoma treated with adjuvant chemotherapy11This work was supported by Grant CB-2011-04-01 from Korean Foundation for Cancer Research grant and by a Global Frontier Project Grant (NRF-M1AXA002-2010-0029795) of the National Research Foundation funded by the Ministry of Education, Science and Technology of Korea. Urol. Oncol. Semin. Orig. Investig. 2014, 32, 49.e23-49.e31. [CrossRef]

57. Akanksha, M.; Sandhya, S. Role of FGFR3 in Urothelial Carcinoma. Iran. J. Pathol. 2019, 14, $148-155$. [CrossRef]

58. Williams, S.V.; Hurst, C.D.; Knowles, M.A. Oncogenic FGFR3 gene fusions in bladder cancer. Hum. Mol. Genet. 2012, 22, 795-803. [CrossRef]

59. Di Martino, E.; Tomlinson, D.C.; Knowles, M.A. A decade of FGF receptor research in bladder cancer: Past, present, and future challenges. Adv. Urol. 2012, 2012, 1-10. [CrossRef]

60. Beukers, W.; van der Keur, K.A.; Kandimalla, R.; Vergouwe, Y.; Steyerberg, E.W.; Boormans, J.L.; Jensen, J.B.; Lorente, J.A.; Real, F.X.; Segersten, U.; et al. FGFR3, TERT and OTX1 as a urinary biomarker combination for surveillance of patients with bladder cancer in a large prospective multicenter study. J. Urol. 2017, 197, 1410-1418. [CrossRef]

61. Hurst, C.D.; Knowles, M.A. Multiomic profiling refines the molecular view. Nat. Rev. Clin. Oncol. 2017, 15, 203-204. [CrossRef] [PubMed]

62. Van Oers, J.M.M.; Zwarthoff, E.C.; Rehman, I.; Azzouzi, A.-R.; Cussenot, O.; Meuth, M.; Hamdy, F.C.; Catto, J.W.F. FGFR3 mutations indicate better survival in invasive upper urinary tract and bladder tumours. Eur. Urol. 2009, 55, 650-658. [CrossRef] [PubMed]

63. Van Rhijn, B.W.G.; van der Kwast, T.H.; Liu, L.; Fleshner, N.E.; Bostrom, P.J.; Vis, A.N.; Alkhateeb, S.S.; Bangma, C.H.; Jewett, M.A.S.; Zwarthoff, E.C.; et al. The FGFR3 mutation is related to favorable pT1 bladder cancer. J. Urol. 2012, 187, 310-314. [CrossRef] [PubMed]

64. Hernandez, S.; Lopez-Knowles, E.; Lloreta, J.; Kogevinas, M.; Amorós, A.; Tardón, A.; Carrato, A.; Serra, C.; Malats, N.; Real, F.X. Prospective study of fgfr3 mutations as a prognostic factor in nonmuscle invasive urothelial bladder carcinomas. J. Clin. Oncol. 2006, 24, 3664-3671. [CrossRef]

65. Critelli, R.; Fasanelli, F.; Oderda, M.; Polidoro, S.; Assumma, M.B.; Viberti, C.; Preto, M.; Gontero, P.; Cucchiarale, G.; Lurkin, I.; et al. Detection of multiple mutations in urinary exfoliated cells from male bladder cancer patients at diagnosis and during follow-up. Oncotarget 2016, 7, 67435. [CrossRef]

66. Frantzi, M.; Makridakis, M.; Vlahou, A. Biomarkers for bladder cancer aggressiveness. Curr. Opin. Urol. 2012, 22, 390-396. [CrossRef]

67. Tomlinson, D.; Baldo, O.; Harnden, P.; Knowles, M. FGFR3 protein expression and its relationship to mutation status and prognostic variables in bladder cancer. J. Pathol. 2007, 213, 91-98. [CrossRef]

68. Christensen, E.; Birkenkamp-Demtröder, K.; Nordentoft, I.; Høyer, S.; van der Keur, K.; van Kessel, K.; Dyrskjøt, L. Liquid biopsy analysis of FGFR3 and PIK3CA hotspot mutations for disease surveillance in bladder cancer. Eur. Urol. 2017, 71, 961-969. [CrossRef]

69. Choi, W.; Porten, S.; Kim, S.; Willis, D.; Plimack, E.R.; Hoffman-Censits, J.; McConkey, D.J. Identification of distinct basal and luminal subtypes of muscle-invasive bladder cancer with different sensitivities to frontline chemotherapy. Cancer Cell 2014, 25, 152-165. [CrossRef] 
70. Hosen, I.; Rachakonda, P.S.; Heidenreich, B.; de Verdier, P.J.; Ryk, C.; Steineck, G.; Hemminki, K.; Kumar, R. Mutations inTERTpromoter andFGFR3and telomere length in bladder cancer. Int. J. Cancer 2015, 137, 1621-1629. [CrossRef]

71. Kompier, L.C.; van der Aa, M.N.; Lurkin, I.; Vermeij, M.; Kirkels, W.J.; Bangma, C.H.; van der Kwast, T.H.; Zwarthoff, E.C. The development of multiple bladder tumour recurrences in relation to the FGFR3mutation status of the primary tumour. J. Pathol. 2009, 218, 104-112. [CrossRef] [PubMed]

72. Kompier, L.C.; Lurkin, I.; van der Aa, M.N.M.; van Rhijn, B.W.G.; van der Kwast, T.H.; Zwarthoff, E.C. FGFR3, HRAS, KRAS, NRAS and PIK3CA mutations in bladder cancer and their potential as biomarkers for surveillance and therapy. PLoS ONE 2010, 5, e13821. [CrossRef] [PubMed]

73. Foth, M.; Ismail, N.F.B.; Kung, J.S.C.; Tomlinson, D.; Knowles, M.A.; Eriksson PIwata, T. FGFR3 mutation increases bladder tumourigenesis by suppressing acute inflammation. J. Pathol. 2018, 246, 331-343. [CrossRef] [PubMed]

74. Pectasides, D.; Bafaloucos, D.; Antoniou, F.; Gogou, L.; Economides, N.; Varthalitis, J.; Athanassiou, A. TPA, TATI, CEA, AFP, $\beta$-HCG, PSA, SCC, and CA 19-9 for monitoring transitional cell carcinoma of the bladder. Am. J. Clin. Oncol. 1996, 19, 271-277. [CrossRef]

75. Järvisalo, J.; Hakama, M.; Knekt, P.; Stenman, U.H.; Leino, A.; Teppo, L.; Maatela, J.; Aromaa, A. Serum tumor markers CEA, CA 50, TATI, and NSE in lung cancer screening. Lung Cancer 1993, 10, 276. [CrossRef]

76. Sjöström, J.; Alfthan, H.; Joensuu, H.; Stenman, U.; Lundin, J.; Blomqvist, C. Serum tumour markers CA 15-3, TPA, TPS, hCG $\beta$ and TATI in the monitoring of chemotherapy response in metastatic breast cancer. Scand. J. Clin. Lab. Investig. 2001, 61, 431-441. [CrossRef]

77. Paavonen, J.; Lehtinen, M.; Lehto, M.; Laine, S.; Aine, R.; Räsänen, L.; Stenman, U.H. Concentrations of tumor-associated trypsin inhibitor and C-reactive protein in serum in acute pelvic inflammatory disease. Clin. Chem. 1989, 35, 869-871. [CrossRef]

78. Lasson, Å.; Borgström, A.; Ohlsson, K. Elevated pancreatic secretory trypsin inhibitor levels during severe inflammatory disease, renal insufficiency, and after various surgical procedures. Scand. J. Gastroenterol. 1986, 21, 1275-1280. [CrossRef]

79. Huhtala, M.-L.; Kahanpää, K.; Seppää, M.; Halila, H.; Stenman, U.-H. Excretion of a tumor-associated trypsin inhibitor (TATI) in urine of patients with gynecological malignancy. Int. J. Cancer 1983, 31, 711-714. [CrossRef]

80. Goumas, P.D.; Mastronikolis, N.S.; Mastorakou, A.N.; Vassilakos, P.J.; Nikiforidis, G.C. Evaluation of TATI and CYFRA 21-1 in patients with head and neck squamous cell carcinoma. ORL 1997, 59, 106-114. [CrossRef]

81. Tramonti, P.G.; Ferdeghini, M.; Donadio, C.; Annichiarico, C.; Norpoth, M.; Bianchi, R.; Bianchi, C. Serum levels of tumor associated trypsin inhibitor (TATT) and glomerular filtration rate. Ren. Fail. 1998, 20, $295-302$. [CrossRef] [PubMed]

82. Stenman, U.-H.; Koivunen, E.; Itkonen, O. Biology and function of tumor-associated trypsin inhibitor, tati. Scand. J. Clin. Lab. Investig. 1991, 51, 5-9. [CrossRef] [PubMed]

83. Stenman, U.-H. Tumor-associated trypsin inhibitor. Clin. Chem. 2002, 48, 1206-1209. [CrossRef] [PubMed]

84. Kelloniemi, E.; Rintala, E.; Finne, P.; Stenman, U.-H. Tumor-associated trypsin inhibitor as a prognostic factor during follow-up of bladder cancer. Urology 2003, 62, 249-253. [CrossRef]

85. Shariat, S.F.; Herman, M.P.; Casella, R.; Lotan, Y.; Karam, J.A.; Stenman, U.-H. Urinary levels of tumor-associated trypsin inhibitor (TATI) in the detection of transitional cell carcinoma of the urinary bladder. Eur. Urol. 2005, 48, 424-431. [CrossRef]

86. Hotakainen, K.; Bjartell, A.; Sankila, A.; Järvinen, R.; Paju, A.; Rintala, E.; Haglund, C.; Stenman, U.-H. Differential expression of trypsinogen and tumor-associated trypsin inhibitor (TATI) in bladder cancer. Int. J. Oncol. 2006, 28, 95-101. [CrossRef]

87. Patschan, O.; Shariat, S.F.; Chade, D.C.; Karakiewicz, P.I.; Ashfaq, R.; Lotan, Y.; Hotakainen, K.; Stenman, U.-H.; Bjartell, A. Association of tumor-associated trypsin inhibitor (TATI) expression with molecular markers, pathologic features and clinical outcomes of urothelial carcinoma of the urinary bladder. World J. Urol. 2011, 30, 785-794. [CrossRef]

(C) 2020 by the authors. Licensee MDPI, Basel, Switzerland. This article is an open access article distributed under the terms and conditions of the Creative Commons Attribution (CC BY) license (http://creativecommons.org/licenses/by/4.0/). 